\title{
Home garden of Sasak people in Sajang Village, Sembalun, East Lombok, Indonesia
}

\author{
Rosalina Edy Swandayani ${ }^{1}$, Luchman Hakim ${ }^{2}$, Serafinah Indriyani ${ }^{3}$ \\ Department of Biology, Faculty of Mathematics and Natural Sciences Brawijaya University \\ Veteran Street, Malang 65145, East Java, Indonesia \\ ${ }^{1}$ rosalinaedy50@gmail.com, ${ }^{2}$ luchman@ub.ac.id, ${ }^{3}$ indriyani.serafinah04@gmail.com
}

\begin{abstract}
The aim of the study is to assess the local people's knowledge in using home garden's plants in Sajang Villagein Sembalun District, East Lombok. Floristic data was done in 105 home gardens along villages corridors to the Mt. Rinjani. Plant species usage among local people was measured using Use Value and Cultural Significant Index. The results showed that there were 279 species of 85 families grows and used by local people. Based on data analysis, Persea americana has the highest UVs $(U V s=1.35)$. It was followed by Curcuma longa $(U V s=1.28)$, Carica papaya $(U V s=1.21)$, Aloe vera $(U V s=1.01)$, Kaempferia galanga $(U V s$ $=0.96)$, Syzygium aromaticum $(U V s=0.95)$. Plants with the highest CSI value is Aloe vera $(C S I=17.04)$. It was followed by Curcuma longa $(C S I=12.00)$, Persea americana $(C S I=9.04)$, Carica papaya $(C S I=8.87)$, Manihot esculenta $(C S I=8.17)$. Plants in home gardens plays an important role in human daily life, including plans as food, traditional medical material, economical and ornamental. The conservation of home garden in Sajang is crucial to maintain biodiversity in rural area and local economic development.
\end{abstract}

Keywords: Home garden, garden conservation, rural tourism.

\section{INTRODUCTION}

Indonesian rural ecosystem was characterized by the existence of home garden. Home garden has been widely studied in tropical developing countries. Home garden provides numerous benefits for people in rural area because home gardens provide numerous functions, ranging from medical to cultural aspects. Home garden is also important as a space to ensure food availability. In the absence of modern market, home garden provides numerous plants resources which area important for human daily life. Home-garden ecosystem is a spot for a variety of flora and fauna, and also a habitat for many species of plants which has economic value, both consumptive or non-consumptive uses [1].

In Indonesia, the diverse tribal and cultural diversity lead to the numerous form of rural space arrangement and managements. According to Statistic of East Lombok [2], there are more than 300 ethnic groups and 1,340 ethnic groups in Indonesia. Most of the tribal community live in rural area and has developed long relationship with its environment, including lands surrounding main house building complex. Therefore, home gardens arrangement and its plants diversity were numerous. There are also numerous local names of home gardens, represent the important role of home garden in human living system. While it is divers in term of space arrangement and plant species and composition, there are similarities in term on management. All of home gardens have been influenced by local knowledge of people on how to manage the space surrounding main building [3].

Local knowledge theoretically could contribute in the utilization of natural resources sustainably. This practices resulting natural beauty, authenticity, and integrity of landscapes. Visual forms of physical and non-physical which ware resulted from traditional management has aesthetic value and perceived by tourist as an outstanding and interesting object and attraction [4].

Home gardens abundance in Lombok Island, but there are few studies has been implemned. This Island has an area of $4738.70 \mathrm{~km}^{2}$ with the topography ranging from flat to undulating with the high point is found in Mt. Rinjani (m asl) [5]. The local people in Lombok Island, called Sasak ethnic group, has been identified live in rural area with abundance home garden. The Sasak people have their own way of managing and utilizing plant diversity based on their local knowledge. The aim of the research is to assess the people's local knowledge in using home garden plants in Sajang Village, Sembalun, East Lombok. 


\section{MATERIALS AND METHODS}

\subsection{Study Site}

The study was conducted in Sajang village which consists of four areas namely Bawak Nau Daya, Bawak Nau Lauk, Lelongkeng, and Sajang. The village is located in the slope of Mt. Gunung Rinjani at $800-900 \mathrm{~m}$ asl. This village is the last village before entering Mt. Rinjani National Park. These villages is home of Sasak people. The majority of Sasak people is traditional farmer.

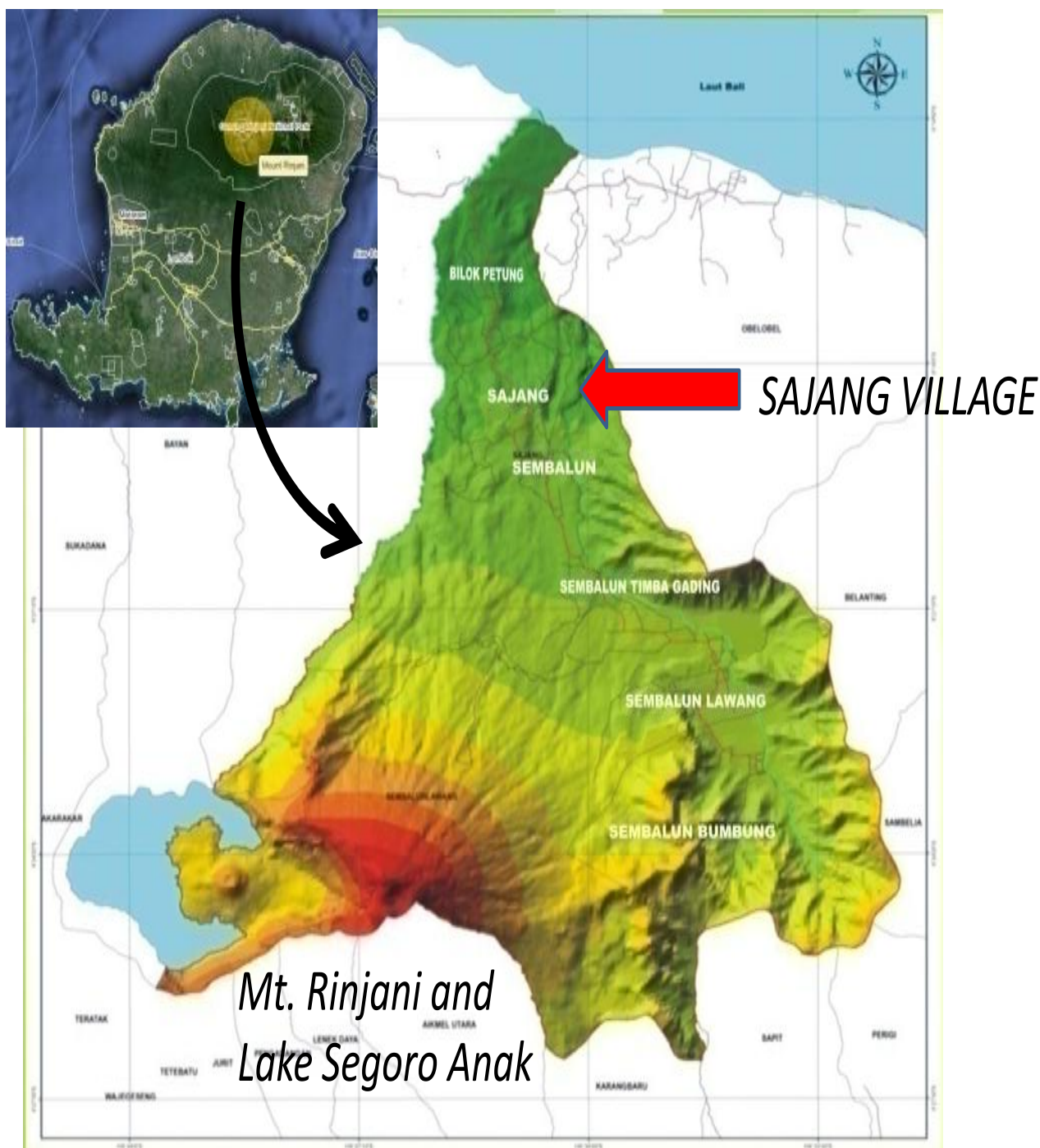

Fig1. The location of Sajang Village in Lombok island, West Nusa Tenggara

\subsection{Data Collection}

The selection of plots is done by purposive sampling [1,6]. About 105 home garden in Sajang village along main rural corridor leading to the Mt. Rinjani National Park was selected as observation plots. In every plots analysis, plant survey was done by direct morphological observation. Plant identification was done in field. The identification of plants is done by matching the morphological features of plants that have been identified in the reference book such as Flora of Java [7] and The Tropical Look An Encyclopedia of Dramatic Landscape Plants [8]. In case of plant unrecognized, some part of the plant organs was collected as herbarium specimen for further analysis in laboratory and Purwodadi Botanical Garden, East Java. In order to generates data related to the uses plants in hoe garden, an interviews was obtained through interviews with 110 people consisting of 105 owners of the home garden and 5 people of village elders. This is done to determine the type of home garden plants and the knowledge of Sajang village people in utilizing these plants.

\subsection{Data Analysis}

Ethnobotanical data related to the use of plant species was calculated using CSI [1,9]. and UVs $[10,11]$. 


\section{RESUlTS AND DisCUSSION}

Based on the research, plants in home gardens has numerous functions, namely ornamental plants, fruit and vegetables and medicinal plants (Fig. 1).. It is similar with other study on the important of plant in home garden $[1,12,13,14,15]$.

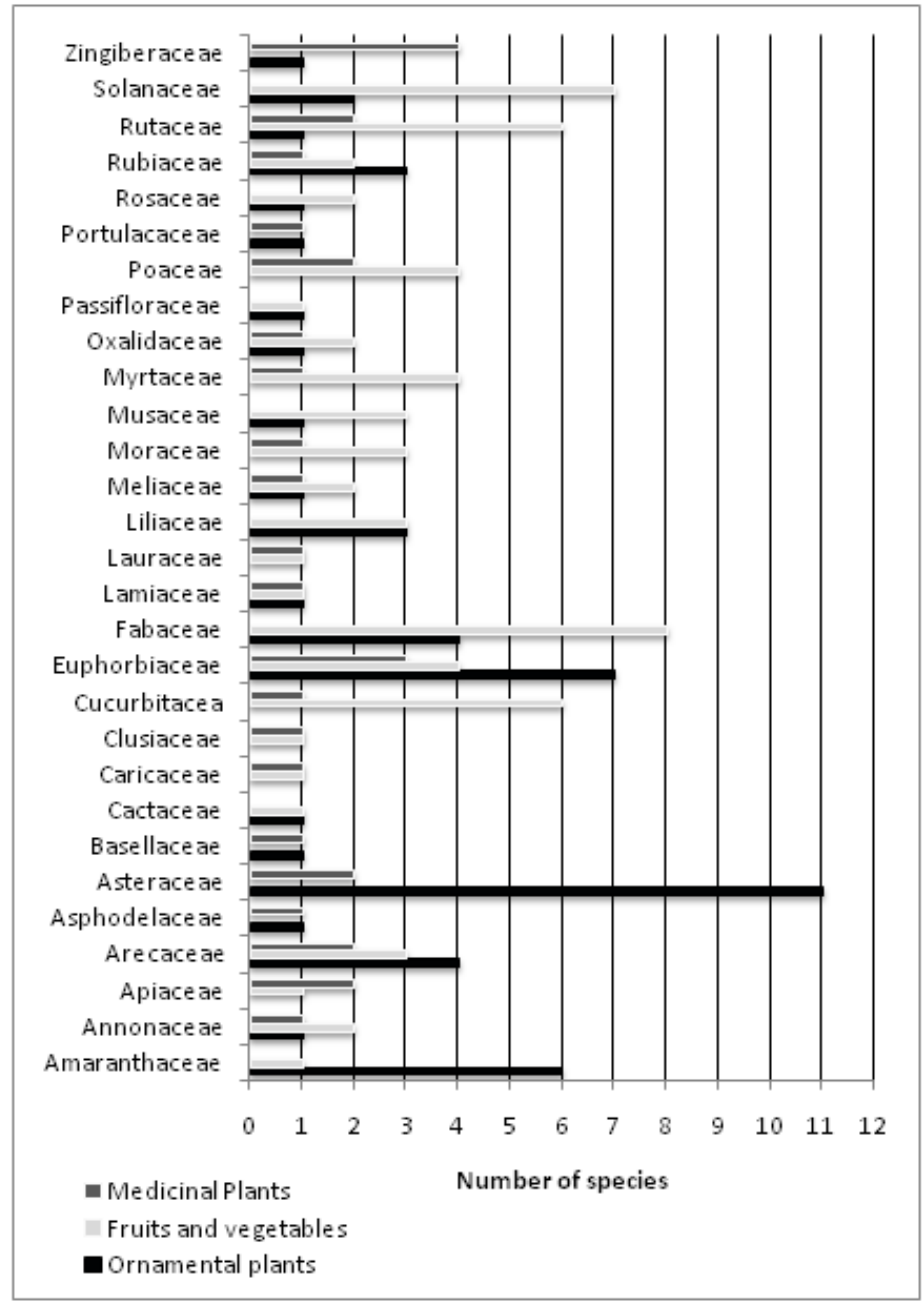

Fig2. Selected family of plant with level of usage more than one type of usage.

Euphorbiaceae is the biggest family (14 species) which area used for medical material (3 species), fruit and vegetable (4 species ) and ornamental plant (3 species). It was followed by Asteraceae with 11 ornamnetal species and medical plant (2 species).

\subsection{Ornamental Plants}

The people of Sajang village usually deliberately plants ornamental plants to beautify the home garden. Ornamental plants have an important function in improving the appearance of houses and buildings through the numerous plant character and color $[1,15]$. Ornamental plants are part of the garden plants that consist of herbs, vines, bushes, shrubs, or trees, which have unique and distinctive shapes and can be used to decorate and beautify the inside and outside's view of the house [16]. Therefore, the presence of various types of ornamental plants in home garden along roads can be used as a tourist attraction. In Sajang village, there are 137 ornamental plants from 57 family which are potentially able to involve in landscaping.

Araceae is a family with high number of ornamental plants (12 species). Generally family Araceae are herbs or shrubs [17]. The Araceae is one of the dominant tropical families that is distributed in tropical and subtropical regions consisting of 105 genera and more than 3,300 species [18,19,20,21]. These species can grow well in in the Sajang village. The examples of Araceae plants are Zamioculcas zamiifolia (Fig. 2a). The Asteraceae family is the second most common types which consists of 11 species. Asteraceae family is a group of plants consisting of 1,100 genera that include 20,000 species. Lawrence [22] mentions that this family is the second largest member of the Plantae 
kingdom. Asteraceae often shows the beautiful flower structure and color, including Rudbeckia hirta, Tagetes patula, Wedelia trilobata. Sasak people in Sajang village planted Asteraceae family in their home garden as ornamental plants to beautify the house environment. Apocynaceae family is the third largest with eight species. The Apocynaceae is distributed in pan-tropical and subtropical regions, but some of them occur in temperate zones and consisting of 411 genera and more than 4,650 species. Ornamental plant belong to Apocynaceae in local home garden encompasses kembang celeng (Allamanda cathartica), kembang jepun beleq (Plumeria acuminata), and kembang jepun kodeq (Adenium obesum).

The ornamental plants are obtained by the people from the forest and partly from several farms in department of agriculture of Sajang village that freely distribute them to the public. Planting ornamental plant in home garden, especially in the front of house is one of the important culture among local people in Sajang. Some ornamental plants commonly utilized by people as the fence is balo ngadang (Euphorbia pulcherrima), kembang keroton (Hibiscus rosa-sinensis), and jernat (Duranta erecta). The Sajang village people generally prefer ornamental plants as the house complex border. There are many benefits using plants as biofence, including easy and cheap in establishment and maintenance, provide multi-functions, and increase house environment health quality.

\subsection{Fruit and Vegetable Plants}

There are 89 species of fruit and vegetables which are included in 36 families in Sajang village homegarden (Fig. 2). The Fabaceae has the highest number of plant species ( 8 species), followed by Solanaceae (7 species) and Cucurbitaceae (6 species). The fruits and vegetables plant is a homegarden provides numerous functions, ranging from sources of healthy food and nutrient to economical value.

Some species of Fabaceae is widely used, including kendokak (Psophocarpus tetragonolobus), buncis (Phaseolus vulgaris) and komak (Canavalia ensiformis). These three plants is a vegetable plant that is always found in the home garden in Sajang village. These vegetable has 3-month harvest period, and can be harvested regularly after fruit was produced by plant species. These species require less management practices and easy to cultivate.

Solanaceae widely used by people in the village as a vegetable. The family is usually in the form of herbs or shrubs [17]. One of the most important Solanaceae is sebie (Capsicum frutescens), which area used intensively by Sasak people as spices in the majority of traditional dish receipt. This species is considered important and cultivated in home garden.

Cucurbitaceae is widely planted in the home-garden of Sajang village. This plant is a herbaceous plant that grows climbing and has stems with cirrhus located close to the leaf [17]. The Cucurbitaceae which are widely used by Sasak people in Sajang village encompasses timun sembalun (Cucumis sativus), baluh (Cucurbita moschata) and jepang (Sechium edule).

\subsection{Medicinal Plants}

There are about 33 plant species from 23 families of plant with medical value was cultivated in home garden in Sajang Village. Zingiberaceae is a family with the most widely used plant as medicine. Zingiberaceae characterized with two rows of leaves with sheaths and has zigomorf flower with hermaphrodites and tubular petals [17]. In Sajang village, there are 4 species of plants in the family that are used as traditional medicine, namely jae (Zingiber officinale), kunyiq (Curcuma longa), sekur (Kaempferia galangal), and temulawak (Curcuma xanthorrhiza). Sasak people in Sajang village use these plants as a tonic drink and skin treatment (boreh). Zingiberaceae is a family with the most used as herbal or traditional medicine by Indonesian people. It is used as a medicine for asthma, rheumatism, dysentery, hypertension and anemia. These species contains anti-carcinogenic substances for the prevention of cancer [23, 24, 25].

Euphorbiaceae is a family with the second most used as a medicinal plant. The family consists of 4 species of plants used by local people. These plants are ambon jawa (Manihot esculenta), jarak ina (Jatropha curcas), and sager (Sauropus androgynus). Cassava or ambon jawa is a shrub with large root tuber used as medicine of dengong, a kind of disease or swelling behind the ear. People usually mix cassava and corn by chewing them and then sprayed on the swelling. People believe that it can help relieve the swelling due to the cooling effect produced on the potion. Besides ambon java, villagers also use jarak ina as a cure for wounds. 
Apiaceae is the third highest family that used as medicinal plants. It has phenolic compounds which potentially as an antioxidant [26]. The most utilized plants by Sasak people encompasses bebele (Centella asiatica) and seledri (Apium graveolens). Bebele (Centella asiatica) is native plant in Indonesia which used as fever .

The people in Sajang village recognize some types of plants in home gardens as a medicinal plant. Recently, however, the tradition to used medical plant uses has changed. Recent generation of Sasak people in Sajang villagers rarely use traditional herbs as medicine and its use is limited to people in the old age. Community with a young age generally prefer a practical way such as midwife and village paramedics.

\subsection{The Importance Value of Species in Hoe Garden}

The importance of each type of plants used by the people in Sajang village was described by CSI value. Based on the analysis, the top ten species with hih value of CSI is presented in Table 1.

Table1. The value of CSI and UVs value of pants species grows in Home garden in Sajang.

\begin{tabular}{|r|l|r|r|}
\hline No & Species & CSI Value & UVs value \\
\hline 1 & Aloe vera L & 17.04 & 1.01 \\
\hline 2 & Artocarpus heterophyllus Lam & 5.45 & 0.86 \\
\hline 3 & Capsicum frutescens L. & 6.14 & 0.5 \\
\hline 4 & Carica papaya L. & 8.87 & 1.21 \\
\hline 5 & Cocos nucifera L. & 6.09 & 0.64 \\
\hline 6 & Coffea arabica L. & 5.22 & 0.86 \\
\hline 7 & Coffea robusta Lindl.Ex De Will & 5.45 & 0.9 \\
\hline 8 & Curcuma longa L. & 12 & 1.28 \\
\hline 9 & Durio zibethinus Murr & 4.52 & 0.7 \\
\hline 10 & Euphorbia pulcherrima Willd. ex Klotzsch & 6.49 & 0.35 \\
\hline 11 & Kaempferia galanga L. & 7.83 & 0.96 \\
\hline 12 & Mangifera indica L. & 6.09 & 0.94 \\
\hline 13 & Manihot esculenta Crantz. & 8.17 & 0.76 \\
\hline 14 & Musa acuminata Colla & 5.04 & 0.7 \\
\hline 15 & Persea americana Mill. & 9.04 & 1.35 \\
\hline 16 & Sauropus androgynus L.) Merr. & 6.67 & 0.7 \\
\hline 17 & Syzygium aromaticum (L.) Merr. \& L. M. Perry & 6.26 & 0.95 \\
\hline 18 & Tagetes erecta L. & 5.74 & 0.54 \\
\hline 19 & Theobroma cacao & 5.33 & 0.62 \\
\hline 20 & Zingiber officinale Rosc. & 7.42 & 0.71 \\
\hline
\end{tabular}

The lidah buaya or Aloe vera with a CSI score of 17.04 was used by the community as an ornamental plant, the heartburn cures, drug tonsils, cough, wound medicine, hair growth, and to care for the skin. This is an ornamental plant which is generally planted at the front of the house. Aloe vera is proved able to reduce plasma glucose that can be used to treat diabetes. In addition it is also used in treating haemorrhoid disease, gonorrhea, cough and tuberculosis [25,27]. Plant with the second highest CSI value is kunyiq or Curcuma longa. Kunyiq is a plant that is used by the villagers as herbs, various types of medicine such as abdominal pain, scar removal as well as a cream for skin diseases. According to the informants, these plants are commonly planted in the home garden behind the house and near pawon or kitchen. Kunyiq extract have anti-obesity effects [28] and antibacterial compounds in these plants [29].

Apokat (Persea Americana) with a CSI value of 9.04 is a fruit plant. This species planted in home gardens as shade plant, economic plant and sources of fuel wood. The fruit and leaves were used as traditional medical material in high blood pressure diseases. The fruit plants with large trees are usually planted scattered by the villagers in their home garden. Steenis et al., (2008) describes this plant is a tree with a height of $3-10 \mathrm{~m}$. The leaves on this plant stemmed and crowding at the end of the branch with flowers androgynous.

Other home garden plants are gedang or Carica papaya. The plant is a shrub-shaped tree with a straight stem and hollow on the inside. The fruit of this plant is berry with lots of seeds [17]. Gedang or papaya has a CSI value of 8.87 commonly used by villagers as fruit and vegetables plant. The other benefit is the leaves of the papaya plant is used by the community as a high blood pressure medication. There are differences in naming this local plant Carica papaya. The Java community, especially people of Tengger called the gedang for banana plants, but on Lombok Island, Sasak community called gedang as papaya fruit [30]. 
Ambon jawa or Manihot esculenta is a common homegarden plants used by the community as a food ingredient, hedgerows and denggong medicine. Denggong is the name of the disease in the Sasak language contained in the form of pain behind the ear accompanied by a high fever that usually affects children. The villagers prepared the medical material by mixing ambon jawa and corn chewed and stick it on the back of the ear that is in pain. Ambon jawa is a homegarden plant in Sajang village with CSI value of 8.17. This plant can grow anywhere and does not require intensive treatment.

Kaempferia galanga or sekur (CSI value 7.83) was planted and used as medicinal herbs. Sekur is used as a cream which is used to treat bruises and smallpox or Edeh. Based on Elfahmi et al., (2014) sekur can be utilized to maintain stamina, reduce fatigue and warm the body. Chemical constituents of this plant is ethyl-pmethoxycinnamate $(31.77 \%)$, methylcinnamate $(23.23 \%)$, carvone $(11.13 \%)$, eucalyptol (9.59\%) and Pentadecane $(6.41 \%)$ [31,32].

Jae or Zingiber officinale (CSI value 7.42) is used as a spice in the kitchen, tonic and as medical material for numerous disease. Sager or Sauropus androgynus which is used as a vegetable, heartburn medicine, increasing milk production of mother with baby-child, food coloring, and midges with a CSI value 6,67. Euphorbia pulcherrima was used as an ornamental plant. Cloves or Syzygium aromaticum are used as a spice and commodities, as well as the perfume ingredient cold medicines. According to Silva et al., [9] and Hakim [1] the value of the CSI can be used to determine the importance of each species of plants used by a group of people in an area.

\subsection{Uvs Analysis}

UVs analysis is used to calculate the overall value of plant use [10,11]. Apokat (Persea americana) is one of the plant species with the highest value of UVs in home garden. This plant is also used by the villagers in various ways such as a shade in the home garden because the trees are large. Avocado leaves can be used as a medicine for patients with high blood pressure or hypertension. Sajang village generally make the medicine by boiling some young leaves of then the cooked water is drunk as a blood pressure medication. Limaa et al., [33] explains that there is the content of leaves of Persea americana hydroalcoholic as anti diabetes with the absorption of glucose in the blood and muscles by $\mathrm{PKB} /$ Akt that has been activated.

Homegarden plants with the second highest utilization value is kunyiq or Curcuma longa. The plants have a UVs value of 1.28 which are used as herbs, upset stomach and skin disease by the villagers. According to Batoro et al., [30] kunyiq is one of the dye plant used by the Tengger people in everyday life. This species also used as a natural food colorants. Gedang or Carica papaya is a home garden plants with the third highest UVs value which is used by people in Sajang village. The value of the UVs is 1.21 which is exploited by the public as fruit, high blood pressure medication and cooked as a vegetable. In addition to high blood pressure medication, Kovendan [34] mentions Carica papaya leaf extract can also be used as an antimalarial drug.

Aloe vera is one of the plants in home garden which are widely used by Sasak people. The plants is used by the community as ornamental and medical plants (UVs 1.01). Other plants that is sekur or Kaempferia galanga with UVs value 0.96, cengkeh or Syzygium aromaticum with UVs value 0.95 and paoq or Mangifera indica with UVs value 0.94. Based on the field research, Sajang Village is the largest coffee-producing village in Sembalun discript. The type of coffee that is cultivated is kopi robusta (Coffea robusta) with UVs value 0.90, and kopi arabika (Coffea Arabica) with UVs value 0.86. There is local knowledge of the communities in coffee cultivation in Sajang village. Society generally perform the grafting technique in the coffee. The type of Robusta coffee is grown on the bottom then the top was connected with arabica coffee species. The grafting result was called kopi Arabusta. Robusta coffee generally have characteristics with strong roots, large trees and live longer than arabica coffee and the fruit is quite large. While Arabica coffee has the characteristics of roots that are not too strong, and a small tree with a lot of coffee seeds and the period of bearing the fruit relatively shorter than the robusta coffee. Sajang villagers apply the grafting technique to produce coffee seeds with Arabica taste but has a harvest period characteristic as robusta coffee. The local community has developed arabica coffee because arabica coffee has high selling prices and become export commodity [2].

Other plants are nangke or Artocarpus heterophyllus (UVs value 0.86). This plant is one of the fruit plants which are commonly found in home garden in Sajang village. According to Steenis et al., [17], nangke or Artocarpus heterophyllus is a monoecious tree with latex adhesive which has a height of 
10-25 m. The fruit is a false fruit that hangs on a twig. Fruits and seeds are consumed by many people. The wood is used for the wooden building where the good wood is yellow and has a sap that is commonly used as a paste and glue to catch birds. As far, there are few technology in nangke processing. In the fruit harvest season, the selling price is very low.

\section{Conclusion}

The results showed that there were 279 species of plants belonging to 85 families and were used by the community as ornamental plants, vegetables and fruits and medicinal plants. Based on the data analysis, the home garden plants with the highest UVs value is Persea Americana (UVs $=1.35$ ). Plants with the highest CSI value is Aloe vera $(\mathrm{CSI}=17,04)$. Home garden in Sajang is an important rural landscapes instrument in biodiversity conservation. The protection and management of home garden therefore is important to ensure the role of home gardens as harbor of biodiversity in rural area.

\section{ACKNOWLEDGEMENTS}

The author would like to thank Brawijaya University that has provided research grants (PHK) 2015 to comple this research. The authors also thank to Mt. Rinjani National Park team and local community in Sajang people who support this study.

\section{REFERENCES}

[1] Hakim L., Etnobotani dan Manejemen Kebun-Pekarangan rumah: Ketahanan Pengan, Kesehatan dan Agrowisata, Selaras, Malang, Indonesia, (2014).

[2] Statistic of East Lombok (BPS), Kecamatan Sembalun dalam Angka 2014, West Nusa Tenggara (2014).

[3] Torquebiau E., Are Tropical Agro forestry Home Gardens Sustainable, Agriculture, Ecosystems \& Environment, Vol 41 (2), 189-207 (1992).

[4] Wickramasinghe A., and Krishna S., Gender and Ecological Sustainability: The Traditions and Wisdom of the Local Communities in a Dry Zone, Sri Lanka, Livelihood and Gender: Equity in Community Resource Management, Vol.171, (2004).

[5] Statistic of West Nusa Tenggara (BPS), Pariwisata Nusa Tenggara Barat 2013, West Nusa Tenggara, (2013b).

[6] Subana and Sudraja, Dasar- Dasar Penelitian Ilmiah, Pustaka Setia, Bandung, (2005)

[7] Backer C. A. and Bakhuizen R.C., Flora of Java, Leiden, Boston, (1968).

[8] Riffle R.L., the Tropical Look an Encyclopedia of Dramatic Landscape Plants, Timber Press, Portland, Oregon (2002).

[9] Silva V.A., Holanda L.D., Andrade C. and Albuquerque U.P., Revising the Cultural Significance Index: The Case of the Fulni-ô in Northeastern Brazil, Field Methods, Vol. 18, 98-108 (2006).

[10] Phillips O. and Gentry A.H., The useful plants of Tambopata , Peru: I. Statistical hypotheses tests with a new quantitative technique, Economic Botany, Vol. 47, 15-32 (1993a).

[11] The useful plants of Tambopata, Peru: II. Additional hypotheses testing in quantitative ethnobotany, Economic Botany Vol. 47, 33-43 (1993b).

[12] Abdoellah O. S., Handikusumah H. Y., Kubota N., and Sugiyama N., Changes in The Performances of Home gardens in West Java For Twenty Years (1) Changes in The Function of Homegardens, Sustainable Agriculture in Rural Indonesia, pp. 112-121 (2002).

[13] Montagnini F., Homegardens of Mesomerica: Biodiversity, food Security, and Nutrient Management dalam: B.M kumar dan P.K.R. Nair (ed) Tropical Home gardens: A Time Tested Example of Sustainable Agro forestry, Springer, Netherland, pp. 61-84 (2006).

[14] Hakim L., and Nakagoshi N., Plant Species Composition in Home Garden in The Tengger Highland (East Java Indonesia) and its Importance for regional Ecotourism Planing. Hikobia. Vol 15, 23-36 (2007).

[15] Sihombing M.A.L., Rohie A.M.C., Februyani N. and Swandayani R.E., Ornamental Plants of Home Garden along the Coridor of Kopendukuh Village, Banyuwangi, East Java-Indonesia as a Basis for Ecotourism Planning, Journal of Indonesian Tourism and Development Studies, Vol. 3(1) (2015). 
[16] Acquaah G., Horticulture-Principles and Practices, Second Edition, Prentice, (2002).

[17] Steenis V.C.G.G.J., Flora: untuk Sekolah di Indonesia, Diterjemahkan oleh Ir. Moeso Surjowinoto, dkk., Penebar Swadaya, Jakarta (2008).

[18] Grayum M. H., Evolution and phylogeny of the Araceae, Annals of the Missouri Botanical Garden, Vol. 77, pp. 628-697 (1990).

[19] Mayo J. S., Bogner J. and Boyce P. C., The Genera of Araceae, London: The European Union and Royal Botanic Gardens, Kew. (1997).

[20] Tam S.H., Boyce P.C., Upson T.M., Barabe D., Bruneau A., Forest F. and Parker J.S., Intergeneric and inframilial phylogeny of subfamily Monsteroideae (Araceae) revealed by chloroplast trnL-F sequences, American Journal of Botany Vol. 91, 490-498 (2004).

[21] Nugroho B.T.A. and Santika Y., Exploration and Inventory of Araceae Genera in Silui Mountain and Uluisimbone Forest, Kolaka Regency, South-East Sulawesi, Journal of Biodiversity ISSN: 1412-033X Vol. 9 (4), 288-291 (2008).

[22] Lawrence G.H.M., Taxonomy of Vascular Plants, The Macmillan Company, New York (1961).

[23] Hatcher H. R., Planalp, Cho J., Torti F. M. and Torti S.V., Curcumin: From Ancient Medicine to Current Clinical Trials, Cellular and Molecular Life Sciences, Vol 65, pp. 1631-52 (2008).

[24] Gupta S. C., Patchva S., Koh W. and Aggarwal B. B., Discovery of Curcumin, a Component of Golden Spice, and its Miraculous Biological Activities, Clinical and Experimental Pharmacology and Physiology Vol. 39, pp. 283-99 (2012).

[25] Elfahmi H., Woerdenbag J. and Kayser O., Jamu: Indonesian Traditional Herbal Medicine Towards Rational Phytopharmacological Use, Journal of Herbal Medicine Vol. 4, pp. 51-73 (2014).

[26] Martins N. L., Barros, Buelga C.S. and Ferreira I.C.F.R., Antioxidant Potential of Two Apiaceae Plant Extracts: A Comparative Study Focused on The Phenolic Composition, Industrial Crops and Products, Vol. 79, 188-194 (2016).

[27] Rajasekaran S., Sivagnanam K., Ravi K. and Subramanian S., Hypoglycemic Effect of Aloe vera Gel on Streptozotocin-induced Diabetesin Experimental Rats, Journal Of Medicinal Food, Vol. 7, 61-66 (2004).

[28] Roh J.S., Lee H., Wee S., Yoon M., Kimb J., Park S.D., Shin S.S. and Yoon M., Herbal Composition Gambigyeongsinhwan (4) from Curcuma longa, Alnus japonica, and Massa Medicata Fermentata in hibits lipid Accumulationin 3T3-L1 Cells and Regulates Obesity in Otsuka Long-Evans Tokushima Fatty rats, Journal of Ethnopharmacology Vol. 171, 287-294 (2015).

[29] Kim K. J., Yu H. H., Cha J. D., Seo S. J., Choi N. Y. and You Y. O., Antibacterial Activity of Curcumalonga Against Methicillin-resistant Staphylococcus aureus, Phytotherapy Research, Vol. 19, 599-604 (2005).

[30] Batoro J., Setiadi D., Chikmawati T. and Purwanto Y., Pengetahuan Tentang Tumbuhan Masyarakat Tengger di Bromo Tengger Semeru Jawa Timur, E-ISSN : I2338-1884 (2008).

[31] Tewtrakul S., Yuenyongsawad Y., Kummee S. and Atsawajaruwan L., Chemical Components and biological activities of volatile oil of Kaempferia galanga Linn., Songklanakarin Journal of Science and Technology, Vol. 27, 503-507 (2005).

[32] Ridtitid W., Chutha S., Wantana R. and Malinee W., Antinociceptive Activity of The Methanolic Extract of Kaempferia galanga Linn. in Experimental Animals, Journal of Ethnopharmacology Vol. 118, 225-230 (2008).

[33] Limaa C. R., Vasconcelosa C. F. B, Costa, Silvab J. H., Maranhãoc, Costad J., Batistae T. M., Carneiroe E. M., Soaresa L.A.L., Ferreiraf F. and Wanderley A.G., Anti-Diabetic Activity of Extract From Persea americana Mill. Leaf via The Activation of Protein Kinase B (PKB/Akt) in Streptozotoc in-Induced Diabetic Rats, Journal of Ethno pharmacology Vol. 141, 517- 525 (2012).

[34] Kovendan K., Murugan K., Panneerselvam C., Aarthi N., Mahesh Kumar P., Subramaniam J., Amerasan D., Kalimuthu K. and Vincent S., Antimalarial Activity of Carica papaya (Family: Caricaceae) Leaf Extract Against Plasmodium falciparum, Asian Pacific Journal of Tropical Disease, S306-S311 (2012). 


\section{AUTHORS' BIOGRAPHY}

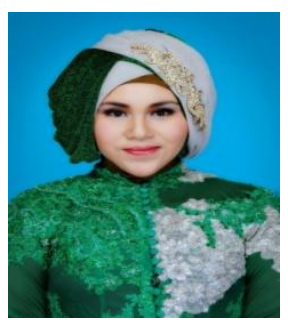

Rosalina Edy Swandayani, born in $1^{\text {th }}$ July, 1990 in Malang, Indonesia. Master student of Department Biology, University of Brawijaya, Malang. Her research focus on ethnobotany of home gardens in Rinjani National Park area, Lombok Island, Indonesia project under coordinator Dr. Luchman Hakim.

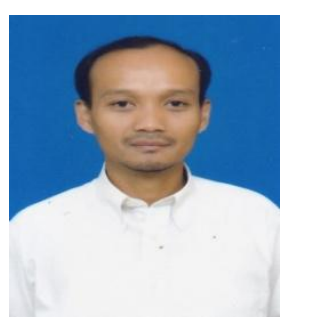

Luchman Hakim, born in Malang (1971). Head of the department of Biology, University of Brawijaya. Research focus on biological conservation and tourism development. He has wrote journals and books related to cultural landscape, conservation, indigenous knowledge and tourism development.

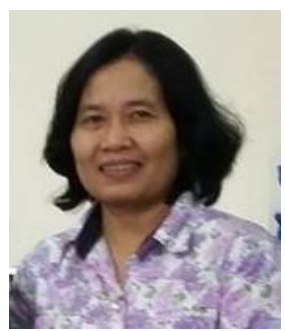

Serafinah Indriyani, born in Surabaya (1963) is a lecture in Department of Biology, Brawijaya University. Completed Doctoral Degree from Airlangga University at 2011. Recently she is working as head of Plant Taxonomy Laboratory, Brawijaya University. Her research focus on the Botany and Agriculture. 